Water Availability and Use Science Program

\title{
Potentiometric Surface of the Mississippi River Valley Alluvial Aquifer, Spring 2016
}

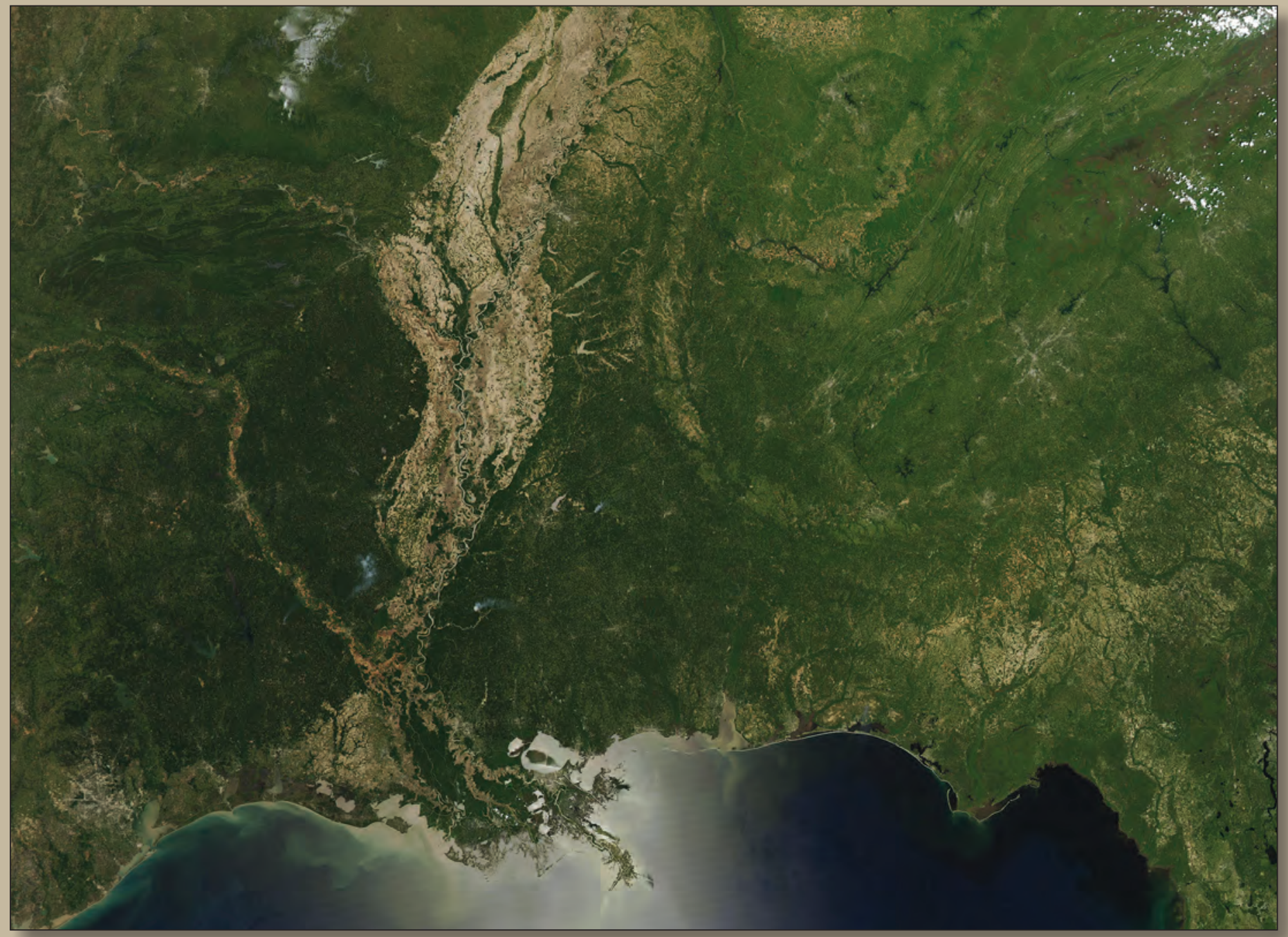

Pamphlet to accompany

Scientific Investigations Map 3439 
Cover. The National Aeronautics and Space Admnistration (NASA) Aqua satellite acquired this image of the Mississippi River alluvial plain on May 4, 2014. Image courtesy of the LANCE/EOSDIS Rapid Response team. 


\section{Potentiometric Surface of the Mississippi River Valley Alluvial Aquifer, Spring 2016}

By Virginia L. McGuire, Ronald C. Seanor, William H. Asquith, Wade H. Kress, and Kellan R. Strauch

Water Availability and Use Science Program

Scientific Investigations Map 3439 


\section{U.S. Department of the Interior DAVID BERNHARDT, Secretary}

\section{U.S. Geological Survey James F. Reilly II, Director}

\section{U.S. Geological Survey, Reston, Virginia: 2019}

For more information on the USGS - the Federal source for science about the Earth, its natural and living resources, natural hazards, and the environment-visit https://www.usgs.gov or call 1-888-ASK-USGS.

For an overview of USGS information products, including maps, imagery, and publications, visit https://store.usgs.gov.

Any use of trade, firm, or product names is for descriptive purposes only and does not imply endorsement by the U.S. Government.

Although this information product, for the most part, is in the public domain, it also may contain copyrighted materials as noted in the text. Permission to reproduce copyrighted items must be secured from the copyright owner.

Suggested citation:

McGuire, V.L., Seanor, R.C., Asquith, W.H., Kress, W.H., and Strauch, K.R., 2019, Potentiometric surface of the Mississippi River Valley alluvial aquifer, spring 2016: U.S. Geological Survey Scientific Investigations Map 3439, 14 p., 5 sheets, https://doi.org/10.3133/sim3439. 


\section{Acknowledgments}

This report is the culmination of efforts by personnel from the Arkansas Natural Resources Commission, Arkansas Department of Health, Arkansas Geological Survey, Illinois Department of Agriculture, Illinois State Water Survey, Louisiana Department of Natural Resources, Louisiana Department of Transportation and Development, Mississippi Department of Environmental Quality, Yazoo Mississippi Delta Joint Water Management District, U.S. Department of AgricultureNatural Resources Conservation Service, U.S. Army Corps of Engineers, and the U.S. Geological Survey's Central Midwest, Lower Mississippi-Gulf, Texas, and Nebraska Water Science Centers, who collected, compiled, organized, analyzed, and verified the groundwater- and surface-wateraltitude data. In addition to the authors, who were primarily responsible for ensuring that the information contained in this report is accurate and complete, the following individuals contributed substantially to the review of the water-level data and related potentiometric surface map:

- Mississippi Department of Environmental Quality: James Hoffmann, Kay Whittington, Sam Mabry, Madison Kymes, and Pat Phillips;

- U.S. Department of Agriculture, Agricultural Research Service: James Robert (JR) Rigby; and

- Yazoo Mississippi Delta Joint Water Management District: Mark Stiles (retired) and David Kelly. 



\section{Contents}

Acknowledgments ….......................................................................................................................

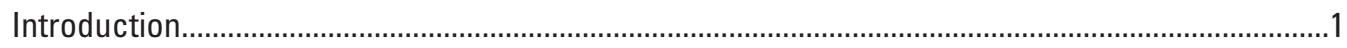

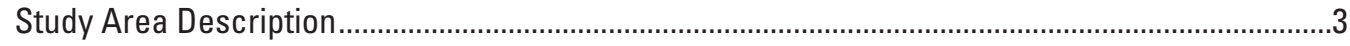

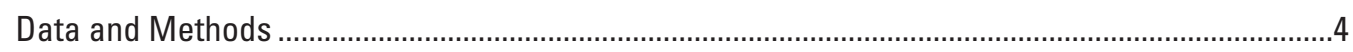

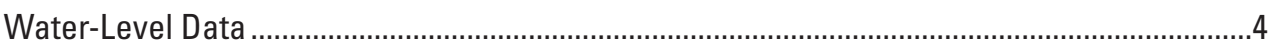

Characterizing the 2016 Potentiometric Surface Raster and Contours.....................................9

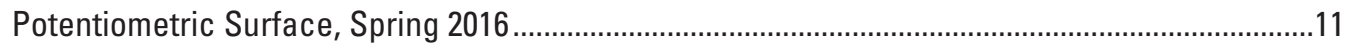

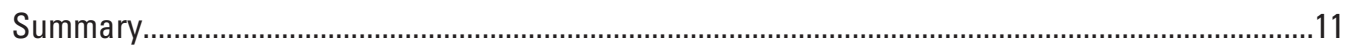

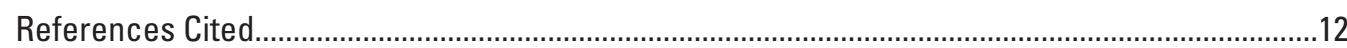

\section{Figures}

1. Map showing the previous and current extent of the Mississippi River Valley alluvial aquifer and areas with insufficient groundwater-altitude data to map the potentiometric surface for spring 2016

2. Map showing location of wells with a water level used to create the potentiometric surface map of the Mississippi River Alluvial aquifer, spring 2016, and the measurement month for the selected water level

\section{Tables}

1. Total number of wells that were completed in the Mississippi River Valley alluvial (MRVA) aquifer and measured manually one or more times or continually from January through May 2016, and the subset of these wells whose groundwater-altitude data were used to generate the potentiometric surface map for the MRVA aquifer, spring 2016, by Mississippi Alluvial Plain (MAP) region...

2. Summary statistics for water-level measurement dates of water levels used in the spring 2016 potentiometric surface map for wells that were completed in the Mississippi River Valley alluvial aquifer and measured manually one or more times or continually as part of groundwater monitoring networks or measured by drillers from January through May 2016, by Mississippi Alluvial Plain (MAP) region...

3. Total number of streamgages in the Mississippi Alluvial Plain (MAP) with surface-water-altitude values from surface-water monitoring networks, in operation for all or part of the time from January through May 2016, and number of streamgages with surface-water-altitude values generally for April 10, 2016, and used to generate the potentiometric surface map for spring 2016 in the Mississippi River Valley alluvial aquifer by MAP region. 


\section{Conversion Factors}

U.S. customary units to International System of Units

\begin{tabular}{lcl}
\hline \multicolumn{1}{c}{ Multiply } & By & \multicolumn{1}{c}{ To obtain } \\
\hline foot $(\mathrm{ft})$ & Length & \\
mile $(\mathrm{mi})$ & 0.3048 & meter $(\mathrm{m})$ \\
\hline & 1.609 & kilometer $(\mathrm{km})$ \\
\hline section $(640 \mathrm{acres}$ or 1 square mile) & Area & \\
square mile $\left(\mathrm{mi}^{2}\right)$ & 259.0 & square hectometer $\left(\mathrm{hm}^{2}\right)$ \\
square mile $\left(\mathrm{mi}^{2}\right)$ & 259.0 & hectare $($ ha) \\
\hline & 2.590 & square kilometer $\left(\mathrm{km}^{2}\right)$ \\
\hline million gallons per day $(\mathrm{Mgal} / \mathrm{d})$ & Flow rate & \\
\hline & 0.04381 & cubic meter per second $\left(\mathrm{m}^{3} / \mathrm{s}\right)$ \\
\hline
\end{tabular}

\section{Datum}

Horizontal coordinate information is referenced to the World Geodetic Survey of 1984 (WGS 84). Historical data collected and stored as North American Datum of 1927 (NAD 27) or the North American Datum of 1983 (NAD 83) have been converted to WGS 84 for use in this publication.

Vertical coordinate information is referenced to the North American Vertical Datum of 1988 (NAVD 88). Historical data collected and stored as National Geodetic Vertical Datum of 1929 have been converted to NAVD 88 for use in this publication.

Altitude, as used in this report, refers to distance above the vertical datum.

\section{Abbreviations}

GIS geographic information system

MAP Mississippi Alluvial Plain

MRVA Mississippi River Valley alluvial

RMSE root mean square error

USGS U.S. Geological Survey 


\title{
Potentiometric Surface of the Mississippi River Valley Alluvial Aquifer, Spring 2016
}

\author{
By Virginia L. McGuire, Ronald C. Seanor, William H. Asquith, Wade H. Kress, and Kellan R. Strauch
}

\section{Introduction}

The Mississippi River Valley alluvial (MRVA) aquifer is an important surficial aquifer in the Mississippi Alluvial Plain (MAP) area. The MRVA aquifer is generally considered to be an unconfined aquifer (fig. 1; Clark and others, 2011). Groundwater withdrawal from the MRVA aquifer are primarily used for irrigation (Maupin and Barber, 2005). These groundwater withdrawals have resulted in substantial areas of water-level declines in parts of the aquifer area. Concerns about waterlevel declines and the sustainability of the MRVA aquifer have prompted the U.S. Geological Survey (USGS), as part of the USGS Water Availability and Use Science Program and with assistance from other Federal, State, and local agencies to undertake a regional water availability study to assess the characteristics of the MRVA aquifer, including the altitude of the MRVA aquifer surface, and to provide information to water managers to inform their decisions about resource allocations and aquifer sustainability.

The purpose of this study was to prepare and present a potentiometric surface map for the MRVA aquifer. The potentiometric surface is a contour map of groundwater-level altitudes (also known as hydraulic heads) in the MRVA aquifer, represented by the water-table elevation in the unconfined parts of the aquifers and by the elevation to which water will rise in a tightly cased well in the confined parts of the aquifer (Lohman, 1972). The potentiometric surface map characterizes pre-irrigation conditions by using groundwater-altitude data, daily mean, or daily maximum groundwater altitude from 1,108 wells generally measured generally in spring 2016 and from altitudes of the top of the water surface in rivers in the area, hereinafter referred to as "surface-water altitude," generally on April 10, 2016, from 48 streamgages in the area. The spring timeframe is after water levels have generally recovered from pumping in the previous irrigation season and before pumping begins for the 2016 irrigation season. Although the MRVA aquifer generally exhibits characteristics of unconfined conditions, where surface-water features may or may not be hydraulically connected, it also exhibits characteristics of confined or semiconfined conditions in some areas at least during part of the year; however, the location of these confined or semiconfined areas is not well understood or defined (Arthur, 1994; Kleiss and others, 2000). The term "potentiometric surface" is used in this report because it is acceptable for maps of groundwater altitude surface in unconfined, semiconfined, and confined aquifers (Lohman, 1972).

Previously published potentiometric surface maps for a large part of the MRVA aquifer include ones from water levels measured from 1953 to 1961 (Krinitzsky and Wire, 1964) and for 1964 (Boswell and others, 1968). Previously published potentiometric surface maps for parts of the MRVA aquifer include ones for the Grand Prairie region in Arkansas in 1929, 1939, and 1959 (Engler and others, 1963) and selected counties in northeast and central Arkansas in 1965 and 1966 (Albin and others, 1967; Plebuch and Hines, 1967); the entire aquifer area in Arkansas for 1972, 1980, 1983, 1984, 1985, 1986, 1987, 1989, 1992, 1994, 1996, 1998, 2000, 2002, 2004, 2006, 2008, and 2012 (Ackerman, 1989; Edds and Fitzpatrick, 1984; Plafcan and Edds, 1986; Plafcan and Fugitt, 1987; Plafcan and Remsing, 1989; Westerfield, 1990; Westerfield and Gonthier, 1993; Westerfield and Poynter, 1994; Stanton and others, 1998; Joseph, 1999; Reed, 2004; Schrader, 2001, 2006, 2008, 2010, 2015); the aquifer area in northwestern Mississippi for various years including 1976, 1980, 1981, 1982, and 1983 (Dalsin, 1978; Wasson, 1980, Darden, 1981, 1982a, 1982b, 1983; Sumner, 1984, 1985; James Hoffmann, Mississippi Department of Environmental Quality, written commun., 2018); the entire aquifer area in Missouri for 1976 (Miller and Appel, 1997); and the part of the aquifer in northeastern Louisiana for 1990 (Seanor and Smoot, 1995).

To best reflect hydrologic conditions in the MRVA aquifer, all groundwater altitudes used to create the 2016 potentiometric surface would have been measured in a short time frame of days or a week and there would be available data (for example, from sets of wells with short screens [for example, 5 to 10 foot (ft) screens] installed near the top, in the middle, and near the bottom of the aquifer) to indicate vertical flow components (Freeze and Cherry, 1979; Fetter, 2001). However, most wells screened in the MRVA aquifer were measured before the potentiometric surface map of the MRVA aquifer was planned and therefore the timing of each well's measurement(s) was determined by the needs and schedules of the entities doing the measurements. Also, many of the measured wells have longer screens, so their waterlevel measurements tend to represent an average hydraulic head in the aquifer for that location (Fetter, 2001). For this 


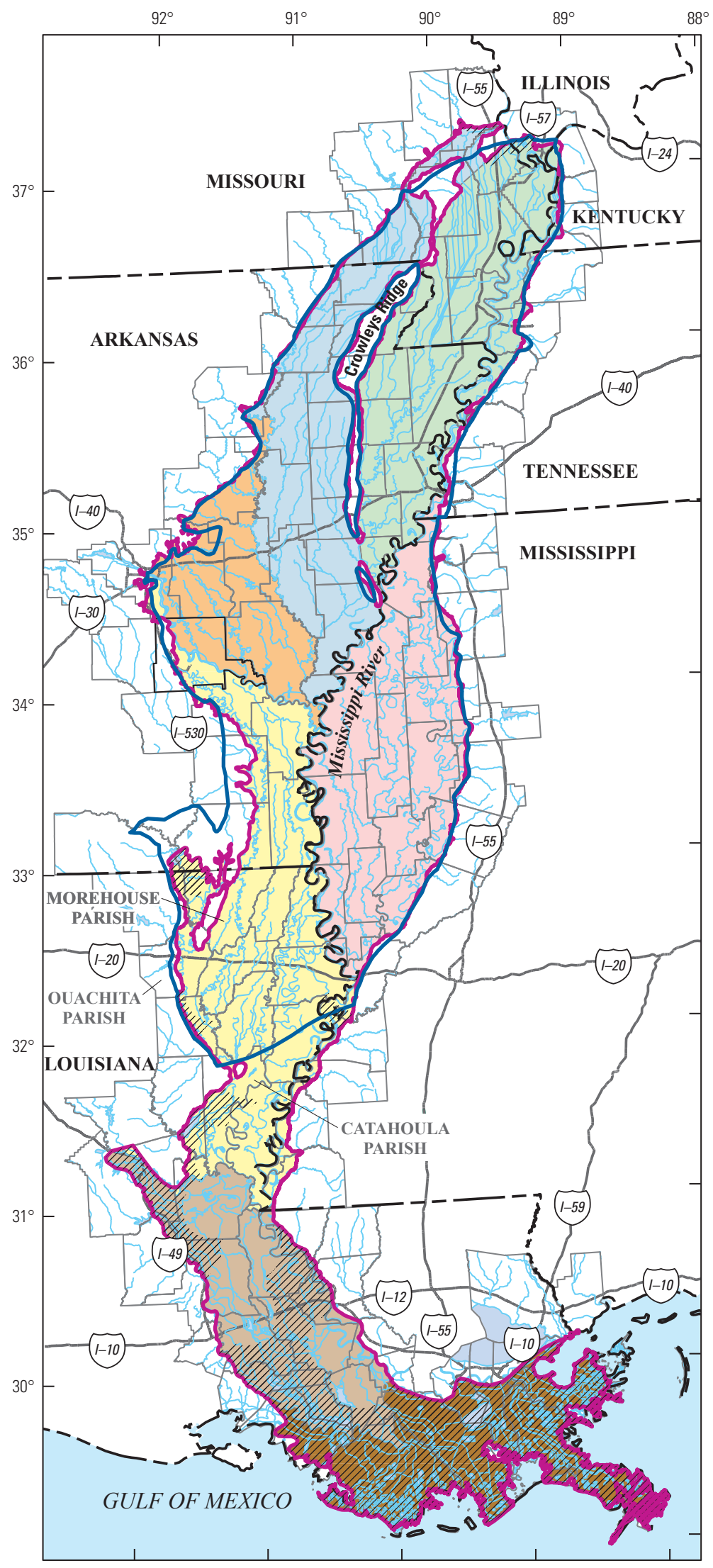

EXPLANATION

Mississippi Alluvial Plain (MAP) Regions

St. Francis

Cache

Grand Prairie

Delta

Boeuf

Atchafalaya

Deltaic and Chenier Plain

VII// Areas of MRVA aquifer with insufficient groundwater-altitude data, spring 2016

MRVA aquifer extent (previous), (U.S. Geological Survey, 2015)

MRVA aquifer extent (current), (Painter and Westerman, 2018)

_ County or parish boundary—Labels shown for selected parishes
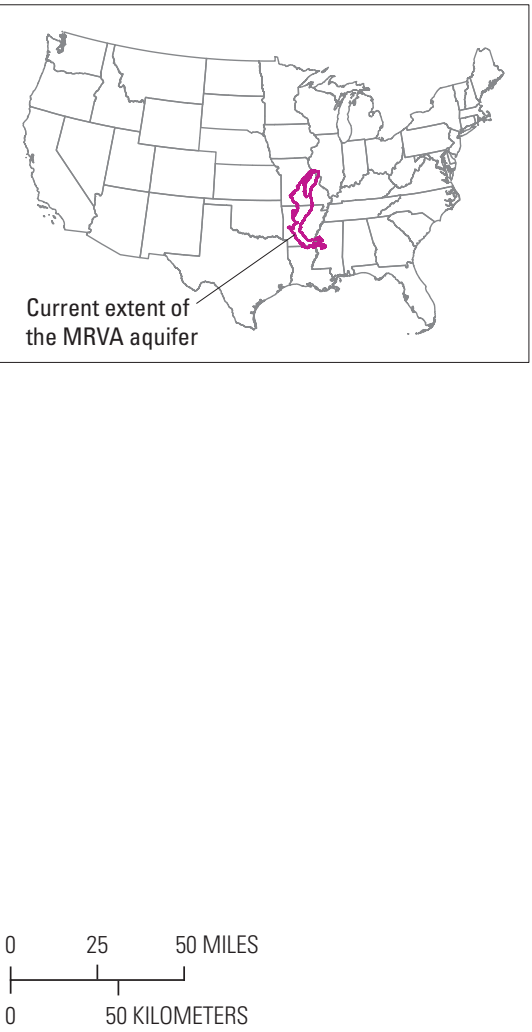

Previous extent of MRVA aquifer (U.S. Geological Survey, 2015) Current extent of MRVA aquifer (Painter and Westerman, 2018) MAP regions (Ladd and Travers, 2019)

Base from U.S. Geological Survey digital data, 1:1,000,000 and 1:2,000,000, variously dated

Highways from National Highway Planning Network, various scales, 2014 Urban areas from U.S. Census Bureau, 1:500,000, 2016

Albers National Hydrogeologic Grid projection

Standard parallels $45^{\circ} 30^{\prime} \mathrm{N}$. and $29^{\circ} 30^{\prime} \mathrm{N}$, central meridian $96^{\circ} 00^{\prime} \mathrm{N}$. World Geodetic Survey of 1984

Figure 1. The previous and current extent of the Mississippi River Valley alluvial (MRVA) aquifer and areas with insufficient groundwater-altitude data to map the potentiometric surface for spring 2016. 
report, recognizing the limitations of the available data, it was decided to assess all available groundwater-altitude data from wells measured from January through May 2016 for use in the potentiometric surface map of the MRVA aquifer representing spring 2016. The resultant potentiometric surface would then represent the generalized central tendency for spring 2016, but it may not be useful for some purposes, such as for calibration of a groundwater flow model for April 1 to April 15, 2016, or for some local scale assessments.

The potentiometric surface map was prepared with the understanding that when an aquifer is unconfined and hydraulically connected to surface-water features, the water table often is a "subdued reflection" of the land surface; and, where crossing surface-water bodies and sufficient groundwaterand surface-water-altitude data exist, bends upgradient or downgradient, depending on whether the surface-water body is losing or gaining water to the aquifer. When an aquifer is unconfined and not hydraulically connected to surface-water features, the water table can be a "subdued reflection" of the land surface, but the water table generally will not be affected by surface-water features. In an unconfined aquifer, the watertable altitude is equal to the hydraulic head. When an aquifer is fully or partially confined, the surface defined by groundwater altitudes in wells, tightly cased in the aquifer, is a map of its hydraulic head, which for a fully or partially confined aquifer contains both a pressure and elevation head. The potentiometric surface of a confined aquifer does not reflect the topography of the land surface and, in situations where wells are flowing, can be above the land surface; in addition, the potentiometric surface of a fully or partially confined aquifer is not affected by surface-water features, such as lakes, streams, or rivers (Fetter, 2001).

\section{Study Area Description}

The MRVA aquifer currently (2019) is defined to be the same as the boundary of the MAP physiographic division, which encompasses a total area of approximately 43,800 square miles $\left(\mathrm{mi}^{2}\right)$ and underlies parts of seven States-Arkansas, Illinois, Kentucky, Louisiana, Mississippi, Missouri, and Tennessee (fig. 1; Painter and Westerman, 2018). The extent of the MRVA aquifer used in this report is a revision of the extent used in previous studies (fig. 1; Clark and others, 2011; Maupin and Barber, 2005; U.S. Geological Survey, 2015). The seven regions of the MRVA aquifer and MAP area are St. Francis and Cache in the north, Boeuf and Grand Prairie in the west-central area, Delta in the east central area, and Atchafalaya and Deltaic and Chenier Plain in the south (fig. 1; Ladd and Travers, 2019).

The percent of the revised MRVA aquifer area (fig. 1) underlying each State is about 34.1 percent in Arkansas, 0.3 percent in Illinois, 0.5 percent in Kentucky, 37.0 percent in Louisiana, 17.8 percent in Mississippi, 8.4 percent in Missouri, and 2.0 percent in Tennessee. The percent of revised MRVA aquifer area within each MAP region is about 12.3 percent in the Atchafalaya region, 20.9 percent in the Boeuf region, 14.4 percent in the Cache region, 16.9 percent in the Delta region, 11.2 percent in the Deltaic and Chenier Plain region, 8.0 percent in the Grand Prairie region, and 16.3 percent in the St. Francis region.

The MRVA aquifer (fig. 1) primarily underlies the Mississippi Alluvial Plain Section within the Atlantic Plain Division and Coastal Plain Province (Fenneman and Johnson, 1946; U.S. Geological Survey, 2004). The MRVA aquifer extends about 560 miles (mi) north to south from southeastern Missouri and Illinois and southwestern Kentucky to the Gulf of Mexico off Louisiana. The width of the MRVA aquifer ranges from about $35 \mathrm{mi}$ in northeast Louisiana and southwest Mississippi to $134 \mathrm{mi}$ in southern Louisiana. The Mississippi River is within the MRVA aquifer boundary except in southeast Louisiana, where the river is north of the aquifer boundary. Where the Mississippi River is within the MRVA aquifer boundary, the river is along the eastern boundary of the northern and southern part of the aquifer; in the central part of the MRVA aquifer, the Mississippi River curves toward the middle of the aquifer at the northwest boundary of Mississippi before curving back toward the eastern boundary of the aquifer about $50 \mathrm{mi}$ south of the northeast boundary of Louisiana (fig. 1).

The MRVA aquifer consists of Quaternary-age sand, gravel, silt, and clay deposits overlying Tertiary-age units (Hosman and Weiss, 1991; Saucier, 1994; Clark and others, 2011). In some areas of the MRVA aquifer, the aquifer is overlain by Quaternary-age semi-confining or confining units of silt and clay; where present, these confining units impede recharge to the MRVA aquifer (Ackerman, 1989; Boswell and others, 1968; Kleiss and others, 2000). There are four areas within the MRVA aquifer extent where the MRVA aquifer is not present (fig. 1). The two northernmost parts of these areas are termed Crowleys Ridge, which is an erosional remnant of Tertiary-age deposits. The Crowleys Ridge areas are about $1,053 \mathrm{mi}^{2}$; the combined length of the two parts of Crowleys Ridge is about $185 \mathrm{mi}$ and the width ranges from less than a mile to about $21 \mathrm{mi}$. Crowleys Ridge forms a physical barrier to groundwater flow in the MRVA aquifer (Schrader, 2015). The other two areas where the aquifer is not present are an upland area of about $128 \mathrm{mi}^{2}$ in northeastern Louisiana in the center of Morehouse Parish and the northeastern part of Ouachita Parish and an upland area of about $21 \mathrm{mi}^{2}$ in the north-central part of Catahoula Parish (fig. 1, Saucier, 1994).

The latest available estimate of water use in the Nation by aquifer is for the year 2000 (Maupin and Barber, 2005). Groundwater withdrawals in 2000 from wells screened in the previously mapped extent of the MRVA aquifer (fig. 1; U.S. Geological Survey, 2015) were 9,290 million gallons per day, making it the third most used aquifer in the Nation (Maupin and Barber, 2005). More than 98 percent of total withdrawals in 2000 from wells completed in the previously mapped extent of the aquifer were for irrigation. Groundwater withdrawals associated with the revised extent of the MRVA aquifer have not been determined. 


\section{Data and Methods}

The 2016 potentiometric surface for this report was created by interpolating the groundwater-altitude data from wells and surface-water-altitude data from streamgages using geographic information system (GIS) software (Esri ${ }^{\circledR}$ ArcMap, version 10.5.1; Esri, 2018). The Esri ${ }^{\circledR}$ ArcMap commands are hereinafter referred to as "GIS commands" and are presented in a fixed-format font, as for example, the command "Topo to Raster." The interpolated potentiometric surface was converted to a raster dataset (grid with a uniform cell size [about $0.386 \mathrm{mi}^{2}$ ] and hereinafter referred to as a "raster"); the potentiometric surface contours were derived from the raster. The point shapefiles of groundwater- and surface-water-altitude data, raster files of the potentiometric surface, and shapefile of the potentiometric surface contours are available in a companion USGS data release (McGuire and others, 2019).

\section{Water-Level Data}

Groundwater-altitude data were compiled by the USGS (table 1; McGuire and others, 2019) from 1,168 wells completed in the MRVA aquifer and measured during January through May 2016. The wells were measured as part of their regular water-level monitoring program by the Arkansas Natural Resources Commission, Arkansas Department of Health, Arkansas Geological Survey, Illinois Department of Agriculture, Illinois State Water Survey, Louisiana Department of Natural Resources, Louisiana Department of Transportation and Development, Mississippi Department of Environmental Quality, Missouri Department of Natural Resources, Yazoo Mississippi Delta Joint Water Management District, U.S. Department of Agriculture (USDA) Natural Resources Conservation Service, and USGS, or were measured by drillers in Missouri. The groundwater altitude in wells that were manually measured one or more times and are not driller-measured, are hereinafter referred to as "manually measured." The groundwater altitude in wells that were measured continually for all or part of the time period, are hereinafter referred to as "continually measured." The groundwater altitude in wells measured by drillers in Missouri during well construction are hereinafter referred to as "driller-measured." The manually, continuously, and drillermeasured water levels were stored in the USGS National Water Information System database (U.S. Geological Survey, 2018) or in a USGS data release (McGuire and others, 2019) as depth to water from land surface. For the manually and driller-measured wells, the land-surface altitude, in feet, and associated vertical datum (National Geodetic Vertical Datum of 1929 [NGVD 29] or North American Vertical Datum of 1988 [NAVD 88]) were retrieved or determined for each well. If the stored land-surface altitude datum was NGVD 29, the land-surface altitude was converted to NAVD 88 using the National Geodetic Survey's VERTCON computer program
(Miller, 1999), and the groundwater altitude with respect to the NAVD 88 was calculated for each well by subtracting depth to water from land-surface altitude. For the continually measured well, the daily mean or maximum groundwater altitude was retrieved and, if necessary, converted to NAVD 88 using National Geodetic Survey's VERTCON computer program (Miller, 1999).

The accuracy of groundwater altitudes from manually and continually measured wells are assumed to be to the hundredths of a foot. The accuracy of the groundwater altitudes from the driller-measured wells are assumed to be 1 to $2 \mathrm{ft}$ because drilling and development activities could affect the measurement and because little documentation was provided about the measurement details (David Smith, USGS Central Midwest Water Science Center, written commun., August 2018).

The 977 manually measured wells were measured one time for about 97 percent of the wells and two or three times for about 3 percent of the wells. There were 18 continuously measured wells in operation for all or part of the time from January to May 2016; a manual measurement was used for one of the continuously measured wells because continuous measurements were not available for this well in early April and a manual measurement was available. There was only one measurement available for each of the 173 driller-measured wells. The groundwater-altitude value for each of the wells was assessed for suitability prior to inclusion in the 2016 potentiometric surface map. The objective of the groundwateraltitude review was to identify and exclude groundwateraltitude values that appeared to be affected by current or recent pumping or were substantially different from the groundwater altitudes in nearby wells, possibly because of local or seasonal conditions. Other considerations for rejecting a well's groundwater altitude were apparent discrepancies between the spatial location of the well and the well's legal description or identifier and suspected inaccuracy in the land-surface altitude value.

For manually measured wells with one measurement and driller-measured wells, the only available measurement was selected as the groundwater altitude to consider for use to create the potentiometric surface map. For the manually measured wells with more than one measurement, generally the maximum (highest) groundwater altitude for each well was selected; the difference between the maximum and minimum groundwater altitude values ranged from 0.22 to $12.64 \mathrm{ft}$, with a median difference of $2.14 \mathrm{ft}$. For the wells measured continuously, the daily mean or maximum (highest) groundwater altitudes in April and May 2016, were reviewed and one value for each well was selected from April 7 to May 12, 2016; the difference between the maximum and minimum groundwater altitude values of the daily maximum or daily mean from April 1 through May 31, 2016, ranged from 0.46 to $22.80 \mathrm{ft}$, with a median difference of $1.91 \mathrm{ft}$.

Groundwater-altitude values from 962 manually measured wells, 17 continuously measured wells, and 129 driller-measured wells were used to create the 2016 
Table 1. Total number of wells that were completed in the Mississippi River Valley alluvial (MRVA) aquifer and measured manually one or more times or continually from January through May 2016, and the subset of these wells whose groundwater-altitude data were used to generate the potentiometric surface map for the MRVA aquifer, spring 2016, by Mississippi Alluvial Plain (MAP) region (Ladd and Travers, 2019).

[--, no data]

\begin{tabular}{|c|c|c|c|c|c|c|c|}
\hline MAP Region & $\begin{array}{c}\text { Total number of } \\
\text { wells in ground- } \\
\text { water-monitoring } \\
\text { networks, which } \\
\text { were measured } \\
\text { manually, } \\
\text { pre-irrigation } \\
\text { season, } 2016\end{array}$ & $\begin{array}{l}\text { Total number of } \\
\text { wells in ground- } \\
\text { water-monitoring } \\
\text { networks, } \\
\text { which were mea- } \\
\text { sured } \\
\text { continually, } \\
\text { pre-irrigation } \\
\text { season, } 2016\end{array}$ & $\begin{array}{c}\text { Total number of wells } \\
\text { in Missouri measured } \\
\text { by drillers after } \\
\text { well installation, } \\
\text { pre-irrigation season, } \\
2016\end{array}$ & $\begin{array}{l}\text { Number of wells in } \\
\text { groundwater- } \\
\text { monitoring networks, } \\
\text { which were measured } \\
\text { manually and used in } \\
\text { potentiometric surface } \\
\text { map, spring } 2016\end{array}$ & $\begin{array}{l}\text { Number of wells in } \\
\text { groundwater- } \\
\text { monitoring networks, } \\
\text { which were measured } \\
\text { continually and used } \\
\text { in potentiometric } \\
\text { surface map, } \\
\text { spring } 2016\end{array}$ & $\begin{array}{l}\text { Number of wells in } \\
\text { Missouri measured by } \\
\text { drillers after well } \\
\text { installation, } \\
\text { which were used } \\
\text { in potentiometric } \\
\text { surface map, } \\
\text { spring } 2016\end{array}$ & $\begin{array}{c}\text { Total number } \\
\text { of wells used } \\
\text { to generate the } \\
\text { potentiometric } \\
\text { surface map, } \\
\text { spring } 2016\end{array}$ \\
\hline St. Francis & 110 & 5 & 128 & 110 & 5 & 92 & 207 \\
\hline Cache & 177 & 7 & 45 & 176 & 7 & 37 & 220 \\
\hline Boeuf & 103 & 1 & -- & 99 & 1 & -- & 100 \\
\hline Grand Prairie & 108 & 4 & -- & 103 & 4 & -- & 107 \\
\hline Delta & 477 & 1 & -- & 472 & -- & -- & 472 \\
\hline Atchafalaya & 2 & -- & -- & 2 & -- & -- & 2 \\
\hline $\begin{array}{l}\text { Deltaic and Cheni } \\
\text { Plain }\end{array}$ & -- & -- & -- & -- & -- & -- & -- \\
\hline $\begin{array}{c}\text { Mississippi River } \\
\text { Valley alluvial } \\
\text { aquifer (total) }\end{array}$ & 977 & 18 & 173 & 962 & 17 & 129 & 1,108 \\
\hline
\end{tabular}


potentiometric surface map (table 1; McGuire and others, 2019). The distribution of the selected wells and the measurement month for the selected groundwater altitude are shown in figure 2, which indicates that if only wells measured in a short timeframe, such as during April 2016, were used to create the 2016 potentiometric surface map, there would be larger areas with no groundwater-altitude data. The measurement month associated with the groundwater-altitude value used for the manually measured wells was January for 3 wells, February for 6 wells, March for 205 wells, April for 649 wells, and May for 99 wells; the median measurement date for all manually measured water levels was April 6, 2016. The measurement month associated with the daily mean groundwater-altitude value used for the continually measured wells was April for 13 wells and May for 4 wells; the median measurement date for all continually measured water levels was April 10, 2016. The measurement month for the driller-measured wells was January for 3 wells, February for 12 wells, March for 41 wells, April for 35 wells, and May for 38 wells; the median measurement date for the driller-measured water levels was April 6, 2016 (fig. 2; table 2).

Daily mean surface-water-altitude data were assembled for 94 streamgages routinely operated by the U.S. Army Corps of Engineers and USGS in the MRVA aquifer area (table 3; U.S. Army Corps of Engineers, 2018; U.S. Geological Survey, 2018; McGuire and others, 2019). For this study, the gage altitude, in feet; the associated vertical datum (NGVD 29 or NAVD 88); and the mean river stage on April 10, 2016, were retrieved for each streamgage. If the vertical datum associated with the gage altitude was NGVD 29, the gage altitude was converted to NAVD 88 using National Geodetic Survey's
VERTCON program (Miller, 1999) for possible use to create the potentiometric surface map.

Of the 94 streamgages considered for use in the potentiometric surface map (table 3), 30 were in areas with little or no groundwater data (defined as no groundwater data within $12.4 \mathrm{mi}$ of the center of the cell that contains the streamgages); 5 did not have surface-water-altitude data in early April 2016; and 11 had surface-water-altitude that was much higher than the nearby wells screened in the MRVA aquifer, likely either because the surface-water altitude was affected by precipitation events or the MRVA aquifer is not connected to the surface water at these locations. There were 48 streamgages in areas with nearby groundwater-altitude data for 2016 used to create the 2016 potentiometric surface (table 3 ). The surfacewater-altitude values were considered to be approximations of the groundwater altitude because the altitude where the groundwater and surface are connected likely is below the surface-water altitude and above the altitude of the river bottom.

The groundwater-altitude data were organized into two files and the surface-water-altitude data were organized into one file (McGuire and others, 2019). Two fields were added to each groundwater- and surface-water-altitude record in each file-the "USE_2016" and "USECMT2016" fields. The "USE_2016" field was assigned a positive value for records with a water-level altitude that was used in the creation of the potentiometric surface map and a negative value for records that were excluded. The "USECMT2016" field is populated for records where the "USE_2016" field is negative and provides an explanation for why the water level was not used for the 2016 potentiometric surface map. 
Table 2. Summary statistics for water-level measurement dates of water levels used in the spring 2016 potentiometric surface map for wells that were completed in the Mississippi River Valley alluvial aquifer and measured manually one or more times or continually as part of groundwater monitoring networks or measured by drillers from January through May 2016, by Mississippi Alluvial Plain (MAP) region (Ladd and Travers, 2019).

[Minimum, maximum, and median columns are shown in YYYYMMDD format; YYYY, year; MM, month; DD, day; --, no data]

\begin{tabular}{|c|c|c|c|c|c|c|c|c|c|c|c|c|}
\hline \multirow{3}{*}{ MAP Region } & \multicolumn{12}{|c|}{$\begin{array}{l}\text { Summary statistics for water-level measurement dates of water levels used in the potentiometric surface map, } \\
\qquad \text { Mississippi River alluvial aquifer, spring } 2016\end{array}$} \\
\hline & \multicolumn{3}{|c|}{$\begin{array}{l}\text { Manually measured wells in } \\
\text { groundwater monitoring networks }\end{array}$} & \multicolumn{3}{|c|}{$\begin{array}{c}\text { Continuously measured wells } \\
\text { in groundwater-monitoring } \\
\text { networks }\end{array}$} & \multicolumn{3}{|c|}{ Driller-measured wells } & \multicolumn{3}{|c|}{ All wells } \\
\hline & Minimum & Maximum & Median & Minimum & Maximum & Median & Minimum & Maximum & Median & Minimum & Maximum & Median \\
\hline St. Francis & 20160314 & 20160512 & 20160427 & 20160427 & 20160525 & 20160428 & 20160105 & 20160530 & 20160412 & 20160105 & 20160530 & 20160425 \\
\hline Cache & 20160308 & 20160513 & 20160405 & 20160127 & 20160531 & 20160507 & 20160301 & 20160523 & 20160404 & 20160127 & 20160531 & 20160405 \\
\hline Boeuf & 20160105 & 20160518 & 20160412 & 20160507 & 20160507 & 20160507 & -- & -- & -- & 20160105 & 20160518 & 20160412 \\
\hline Grand Prairie & 20160229 & 20160505 & 20160316 & 20160407 & 20160507 & 20160411 & -- & -- & -- & 20160229 & 20160507 & 20160316 \\
\hline Delta & 20160401 & 20160430 & 20160406 & -- & -- & -- & -- & -- & -- & 20160401 & 20160430 & 20160406 \\
\hline Atchafalaya & 20160104 & 20160105 & 20160104 & -- & -- & -- & -- & -- & -- & 20160104 & 20160105 & 20160104 \\
\hline $\begin{array}{l}\text { Deltaic and Cheni } \\
\quad \text { Plain }\end{array}$ & -- & -- & -- & -- & -- & -- & -- & -- & -- & -- & -- & -- \\
\hline $\begin{array}{l}\text { Mississippi River } \\
\text { Valley alluvial } \\
\text { aquifer }\end{array}$ & 20160104 & 20160518 & 20160406 & 20160127 & 20160531 & 20160502 & 20160105 & 20160530 & 20160406 & 20160104 & 20160531 & 20160406 \\
\hline
\end{tabular}




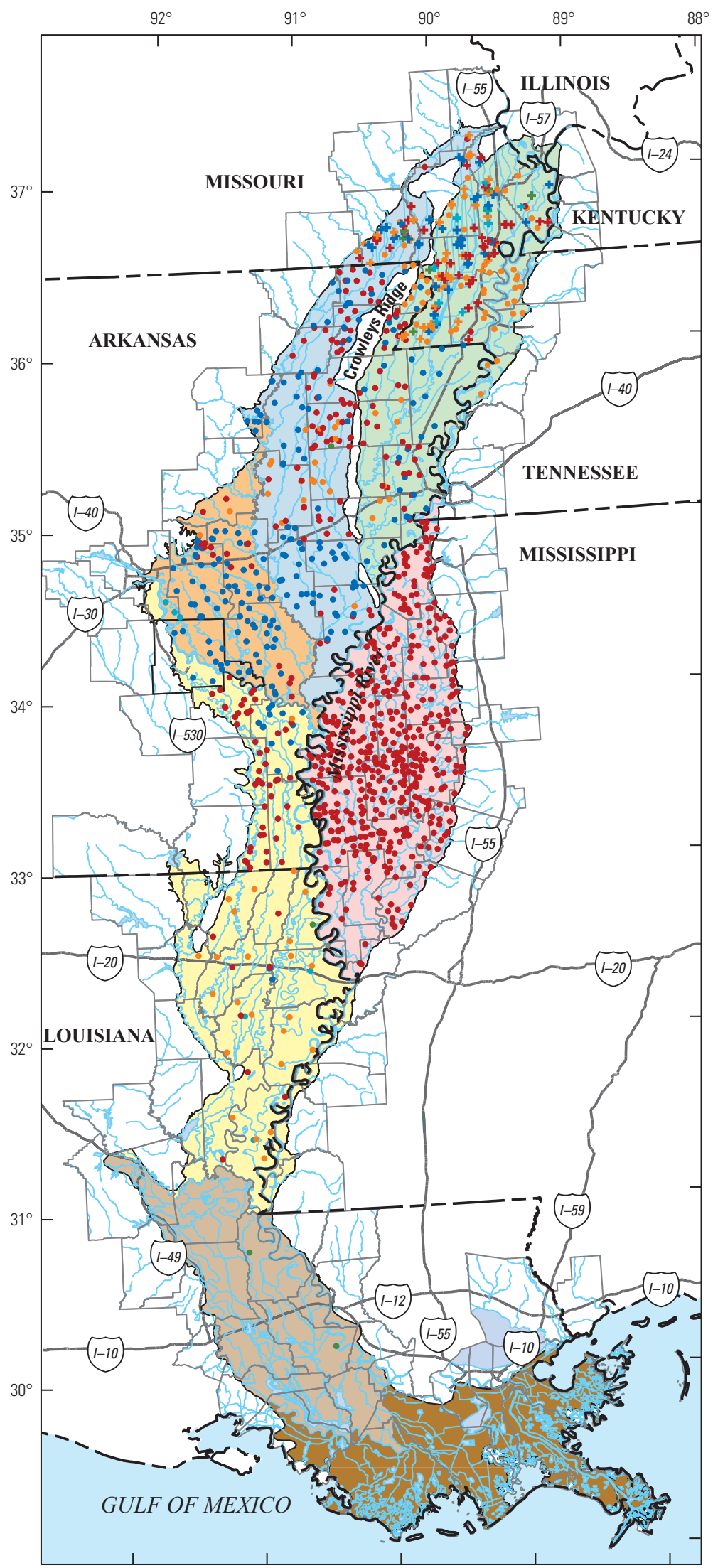

EXPLANATION

Mississippi Alluvial Plain (MAP) Regions

St. Francis

Cache

Grand Prairie

Delta

Boeuf

Atchafalaya

Deltaic and Chenier Plain

County or parish boundary

Measured wells in groundwater-monitoring networks Water-level measurement month

- January 2016

- February 2016

- March 2016

- April 2016

- May 2016

Driller-measured wells

Water-level measurement month

$+\quad$ January 2016

+ February 2016

$+\quad$ March 2016

+ April 2016

$+\quad$ May 2016

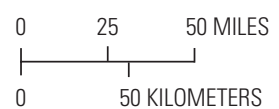

Current extent of MRVA aquifer (Painter and Westerman, 2018) MAP regions (Ladd and Travers, 2019)

Base from U.S. Geological Survey digital data, 1:1,000,000 and 1:2,000,000 variously dated

Highways from National Highway Planning Network, various scales, 2014 Urban areas from U.S. Census Bureau, 1:500,000, 2016

Albers National Hydrogeologic Grid projection

Standard parallels $45^{\circ} 30^{\prime} \mathrm{N}$. and $29^{\circ} 30^{\prime} \mathrm{N}$, central meridian $96^{\circ} 00^{\prime} \mathrm{N}$. World Geodetic Survey of 1984

Figure 2. Location of wells with a water level used to create the potentiometric surface map of the Mississippi River Alluvial (MRVA) aquifer, spring 2016, and the measurement month for the selected water level. 
Table 3. Total number of streamgages in the Mississippi Alluvial Plain (MAP) with surface-water-altitude values from surface-water monitoring networks, in operation for all or part of the time from January through May 2016, and number of streamgages with surfacewater-altitude values generally for April 10, 2016, and used to generate the potentiometric surface map for spring 2016 in the Mississippi River Valley alluvial aquifer by MAP region (Ladd and Travers, 2019).

$[--$, no data $]$

\begin{tabular}{lcc}
\hline MAP Region & $\begin{array}{c}\text { Number of streamgaging stations with } \\
\text { surface-water altitude values for all or part } \\
\text { of the time period from January to May 2016 }\end{array}$ & $\begin{array}{c}\text { Number of surface-water altitude values } \\
\text { generally for April 10, 2016, and used to } \\
\text { generate the potentiometric surface } \\
\text { map of 2016 }\end{array}$ \\
\hline St. Francis & 5 & 5 \\
Cache & 11 & 7 \\
Boeuf & 20 & 15 \\
Grand Prairie & 1 & -- \\
Delta & 13 & 8 \\
Atchafalaya & 21 & 13 \\
Deltaic and Chenier Plain & 23 & -- \\
Mississippi River Valley alluvial aquifer (total) & 94 & 48 \\
\hline
\end{tabular}

\section{Characterizing the 2016 Potentiometric Surface Raster and Contours}

The potentiometric surface raster and contours were generated using a series of GIS commands and three source files of groundwater- and surface-water-altitude data from January to May 2016 (McGuire and others, 2019). For each source file, only the groundwater- and surface-altitude data with a value greater than zero for the field attribute "USE_2016" were used to generate the potentiometric surface for 2016. The resultant spatial files are in Albers equal-area conic projection in meters with respect to the World Geodetic Survey of 1984 (WGS 84) horizontal datum and the potentiometric surface altitude is expressed relative to NAVD 88 vertical datum. The rasters have a cell size of 1,000 meters and are aligned with the National Hydrologic Grid (Clark and others, 2018).

The steps used to generate the potentiometric surface for 2016 can be divided into three workflows: data preparation and other activities prior to analysis, analysis, and final map preparation. These workflows are described in detail in the process steps within the metadata files for the raster and contours of the potentiometric surface (McGuire and others, 2019) and briefly described below:

- Description of the data preparation and other activities prior to analysis workflow:

- The sparse groundwater-altitude data for 2016 in Louisiana was assessed separately with groundwater- and surface-water-altitude data for 2018 to determine if surface-water-altitude data for 2016 could be used to estimate groundwater altitude in the 2016 potentiometric surface map. The 2018 groundwater data considered were for USGS station numbers equal to USGS 300619091053701 , USGS 300645091085301, USGS 302528091543101, USGS 302827091301201, USGS 302934091571001, and USGS 303310091493401; the 2018 streamgage data considered were for USGS station numbers equal to USGS 07380400 , USGS 07380401, USGS 07380500, USGS 07384400, USGS 07386600 , USGS 07386850, USGS 301655091440800 , USGS 302020091435700, and USGS 302320091465900 (U.S. Geological Survey, 2018). Because of this evaluation, 2016 surface-water-altitude data from these streamgages were used as the estimated groundwater altitude at those locations in the 2016 potentiometric surface map (McGuire and others, 2019).

- Areas of the aquifer with little groundwater-altitude data were identified using the GIS "Euclidean Distance" command. These areas with little groundwater-altitude data for 2016 were defined as cells that were generally about $12.4 \mathrm{mi}$ or more from the center of the cell to the nearest well with a groundwater altitude, which was used in the 2016 potentiometric surface map. The areas with little groundwater-altitude data for 2016 were a total of about $8,500 \mathrm{mi}^{2}$, or about 19 percent of the MRVA aquifer area. About 81 percent of the aquifer area were assumed to have sufficient groundwater data for 2016 to create a potentiometric surface map for spring 2016. 
- Description of the analysis workflow:

- The interpolations to create rasters of the potentiometric surface for the two aquifer sections were done using the GIS command "Topo to Raster." The input data included the following:

- Groundwater altitudes from subsets of the two files of groundwater altitude data and surfacewater altitude from a subset of the streamgage file, where the "USE_2016" field was greater than zero;

- The MRVA aquifer boundary in two sectionsone on the east side of Crowleys Ridge and the other on the west side of Crowleys Ridge (combined with the remaining aquifer area); and

- For all interpolations after the initial run, potentiometric surface contours were had been manually modified to guide the interpolation, especially in areas with little data or in areas near streams.

- The potentiometric surfaces for the two sections were combined using the GIS "merge" command, and contours of the merged potentiometric surface were created using the GIS "contour" commands.

- In March 2018, a collaborator with considerable knowledge about the MRVA aquifer in Mississippi manually contoured the potentiometric surface in Mississippi and provided feedback on potential location and land-surface altitude problems associated with the manually measured groundwater-altitude data (James Hoffmann, Mississippi Department of Environmental Quality, written commun., March 2018). If the data problems could not be resolved, the "USE_2016" field was set to a negative value. In addition, the manual contours were georeferenced and digitized, and the manually modified contours generated in the prior process step were updated using the contours drawn by the collaborator (James Hoffmann, Mississippi Department of Environmental Quality, written commun., March 2018) and the updated groundwater-altitude values and locations as guides.

- The potentiometric surface raster, which was output from the interpolation process, was compared to a raster of the aquifer base (Saucier, 1994; Wilson and Hosman, 1987; Hart and others, 2008; James Hoffmann, Mississippi Department of Environmental Quality, written commun., February 2018; Joseph Richards, U.S. Geological Survey, written commun., March 2018; Wacaster and others, 2018) to identify where the input potentiometric surface raster was below the aquifer-base raster.
The input potentiometric surface raster was below the aquifer-base raster in about 1 percent of the aquifer area, all in the northwestern part of the aquifer in southeastern Missouri. No changes were made to the input potentiometric surface raster as a result of this comparison because there were groundwater-altitude data for nine wells screened in the MRVA aquifer in these areas. The well identification (also termed site-badge) codes for these wells are USGS:364529089550501, MO000:517234, MO000:517231, MO000:517233, MO000:304550, MO000:506283, MO000:304521, MO000:517195, and MO000:506299 (McGuire and others, 2019).

- This workflow was repeated as often as necessary until the potentiometric surface was finalized.

- Description of the map preparation workflow:

- Lines perpendicular to the potentiometric surface contours were generated at selected locations and added to the potentiometric surface map, with arrow heads indicating flow direction.

- A total of five potentiometric maps were created - one for the entire MRVA aquifer, and one each for the St. Francis and Cache MAP regions in the north, Boeuf and Grand Prairie MAP regions in the west-central area, Delta MAP region in the east-central area, and Atchafalaya and Deltaic and Chenier Plain MAP regions in the south. The map of the entire MRVA area is presented at a scale of $1: 1,325,000$ and shows the labeled contours and unlabeled control point values. The four maps of 1 or 2 MAP regions are presented at a reduced, scale of 1:625,000 to allow for the display of control point values.

The interpolation process, which was used to generate the rasters, can result in cell values for cells collocated with a measured well that are generally similar to, but commonly not equal to, the corresponding groundwater- and surfacewater-altitude values based on measurements. This difference is partly because the cell values represent the value for the cell area, and the measured values are values at specific locations within the area represented by the cell.

To assess the uncertainty in the final contours, the water-level altitude for all values considered in the potentiometric surface map and for all values used to generate the potentiometric-surface raster were compared to the final potentiometric-surface raster value in the cell where the well or streamgage is located (McGuire and others, 2019). The root mean square error (RMSE) and bias were calculated for the difference between the manually or driller measured water-level altitude and the value extracted from the potentiometric-surface raster generated using the contours (Helsel and Hirsch, 2002). 


\section{Potentiometric Surface, Spring 2016}

Based on water-level altitude values from 1,108 wells and 48 streamgages, the 2016 potentiometric contours ranged from 10 to $340 \mathrm{ft}$ above NAVD 88, and the regional direction of groundwater flow was to the south-southwest, except in areas of groundwater-altitude depressions (sheet 1), where groundwater flowed into the depression, and near rivers, where flow was generally parallel to the rivers. However, in some areas, flow was from the aquifer into the river or from the river into the aquifer. The lowest measured groundwater altitude was $22.51 \mathrm{ft}$ in Iberville Parish, La., and the highest was $339.87 \mathrm{ft}$ in Bollinger County, Mo.; the lowest measured surface-water altitude was $3.39 \mathrm{ft}$ in Lafayette Parish, La., and the highest was $348.60 \mathrm{ft}$ in Bollinger County, Mo. (McGuire and others, 2019). Based on groundwater- and surface-wateraltitude measurements from January to May 2016, the MRVA aquifer is connected to surface-water features in some areas and disconnected in other areas at least during part of the year; however, the extent of these areas degree of connectivity cannot be derived from these data.

The RMSE for the difference between the measured water-level altitude for the 16 manually measured and 44 driller measured wells that were not used in the potentiometric surface map was $40 \mathrm{ft}$ and $24 \mathrm{ft}$, respectively. The RMSE for the difference between the measured water-level altitude for the 1,108 manually and driller measured wells that were used in the potentiometric surface map, was $2 \mathrm{ft}$ with a bias of $-0.34 \mathrm{ft}$.

The 2016 potentiometric contours in the Cache regionranged from 120 to $340 \mathrm{ft}$ and show a large depression in the lower half of the Cache region (sheet 2). The lowest measured groundwater altitude was $116.21 \mathrm{ft}$ in a depression in Poinsett County, Ark., and the highest measured groundwater altitude was $339.87 \mathrm{ft}$ in Bollinger County, Mo.; the lowest measured surface-water altitude was $174.56 \mathrm{ft}$ in Prairie County, Ark., and the highest was $348.60 \mathrm{ft}$ in Bollinger County, Mo. (McGuire and others, 2019). Flow in the Cache region generally is to the south-southwest or into the depression in the southern part of the region.

The 2016 potentiometric contours in the St Francis region ranged from 170 to $310 \mathrm{ft}$ (sheet 2). The lowest measured groundwater altitude was $160.61 \mathrm{ft}$ in Saint Francis County, Ark., and the highest measured groundwater altitude was $313.98 \mathrm{ft}$ in Mississippi County, Mo.; the lowest measured surface-water altitude was $273.43 \mathrm{ft}$ in New Madrid County, Mo., and the highest was $298.07 \mathrm{ft}$ in Alexander County, Ill. (McGuire and others, 2019). Flow in the St. Francis region generally is to the south-southwest.

The 2016 potentiometric contours in the Boeuf region ranged from 30 to greater than $220 \mathrm{ft}$ (sheet 3 ). The lowest measured groundwater altitude was $35.25 \mathrm{ft}$ in Concordia Parish, La., and the highest measured groundwater altitude was $181.95 \mathrm{ft}$ in Jefferson County, Ark.; the lowest measured surface-water altitude was $31.51 \mathrm{ft}$ in Concordia Parish, La., and the highest was $231.09 \mathrm{ft}$ in Pulaski County, Ark.
(McGuire and others, 2019). Flow in the Boeuf region generally is to the southeast and southwest.

The 2016 potentiometric contours in the Grand Prairie region range from 80 to $220 \mathrm{ft}$; there is a large depression in the potentiometric surface within the region (sheet 3 ). The lowest measured groundwater altitude was $72.08 \mathrm{ft}$ in Arkansas County, Ark., and the highest measured groundwater altitude was $228.33 \mathrm{ft}$ in Lonoke County, Ark. (McGuire and others, 2019). Flow in the Grand Prairie region generally is into the depression that encompasses most of the region.

The 2016 potentiometric contours in the Delta region range from 60 to $200 \mathrm{ft}$; there is a large depression in the potentiometric surface within central part of the region (sheet 4). The lowest measured groundwater altitude was $57.96 \mathrm{ft}$ in Sunflower County, Miss., and the highest measured groundwater altitude was $199.39 \mathrm{ft}$ in DeSoto County, Miss.; the lowest measured surface-water altitude was $84.40 \mathrm{ft}$ in Warren County, Miss., and the highest was $200.02 \mathrm{ft}$ in Shelby County, Tenn., (McGuire and others, 2019). Flow in the Delta region generally is into the large depression and toward the south.

For most of the Atchafalaya region and all of the Deltaic and Chenier Plain region, potentiometric contours for spring 2016 could not be created because there were no groundwateraltitude data (sheet 5). In the part of the Atchafalaya region included in the 2016 potentiometric surface map, potentiometric contours ranged from 10 to $30 \mathrm{ft}$ (sheet 5). The lowest measured groundwater altitude was $22.51 \mathrm{ft}$ in Iberville Parish, La., and the highest measured groundwater altitude was $24.48 \mathrm{ft}$ in Pointe Coupee Parish, La.; the lowest measured surface-water altitude was $3.39 \mathrm{ft}$ in Lafayette Parish, La., and the highest was $28.57 \mathrm{ft}$ in Avoyelles Parish, La. (McGuire and others, 2019). Groundwater flow in the mapped area is generally toward the south and southwest.

\section{Summary}

A potentiometric surface map for spring 2016 was created for the Mississippi River Valley alluvial (MRVA) aquifer using available groundwater-altitude data from 1,108 wells completed in the MRVA aquifer and from the altitude of the top of the water surface in area rivers from 48 streamgages. Personnel from the Arkansas Natural Resources Commission, Arkansas Department of Health, Arkansas Geological Survey, Illinois Department of Agriculture, Illinois State Water Survey, Louisiana Department of Natural Resources, Louisiana Department of Transportation and Development, Mississippi Department of Environmental Quality, Missouri Department of Natural Resources, Yazoo Mississippi Delta Joint Water Management District, U.S. Department of Agriculture Natural Resources Conservation Service, U.S. Geological Survey (USGS), and drillers in Missouri routinely collect groundwater-level data from wells screened in the MRVA aquifer. The USGS and the U.S. Army Corps of Engineers 
routinely collect data on river stage and discharge for the rivers overlying the MRVA aquifer area. The potentiometric surface map for 2016 was created utilizing existing groundwater and surface-water altitudes to support investigations to characterize the MRVA aquifer as part of the USGS Water Availability and Use Science Program.

Sufficient data exist to map the potentiometric surface of the MRVA aquifer for spring 2016 for about 81 percent of the aquifer area. The lowest measured groundwater altitude was 22.51 feet (ft) in Iberville Parish, La., and the highest was $339.87 \mathrm{ft}$ in Bollinger County, Mo.; the lowest measured surface-water altitude was $3.39 \mathrm{ft}$ in Lafayette Parish, La., and the highest was $348.60 \mathrm{ft}$ in Bollinger County, Mo. The potentiometric contours ranged from 10 to $340 \mathrm{ft}$ above North American Vertical Datum of 1988. The regional direction of groundwater flow was generally to the south-southwest, except in areas of groundwater-altitude depressions, where groundwater flowed into the depression, and near rivers, where flow can be from aquifer to the river or from the river into the aquifer. There are large depressions in the potentiometric surface in the lower half of the Cache region and in most of the Grand Prairie and Delta regions.

\section{References Cited}

Ackerman, D.J., 1989, Hydrology of the Mississippi River Valley alluvial aquifer, south-central United States-A preliminary assessment of the regional flow system: U.S. Geological Survey Water-Resources Investigations Report 88-4028, 74 p. [Also available at https://doi.org/10.3133/ wri884028.]

Albin, D.R., Hines, M.S., and Stephens, J.W., 1967, Water resources of Jackson and Independence Counties, Arkansas; Contributions to the Hydrology of the United States: U.S. Geological Survey Water Supply Paper 1839-G, 29 p. [Also available at URL https://doi.org/10.3133/wsp1839G.]

Arthur, J.K., 1994, Thickness of the upper and lower confining units of the Mississippi River alluvial aquifer in northwestern Mississippi: U.S. Geological Survey Water-Resources Investigations Report 94-4172, 1 pl. [Also available at https://pubs.usgs.gov/wri/1994/4172/plate-1.pdf.]

Boswell, E.H., Cushing, E.M., Hosman, R.L., and Jeffery, H.G., 1968, Quaternary aquifers in the Mississippi embayment, with a discussion of quality of the water: U.S. Geological Survey Professional Paper 448-E, 15 p., 2 pls. [Also available at https://doi.org/10.3133/pp448E.]
Clark, B.R., Barlow, P.M., Peterson, S.M., Hughes, J.D., Reeves, H.W., and Viger, R.J., 2018, National-scale grid to support regional groundwater availability studies and a national hydrogeologic database: U.S. Geological Survey data release, accessed July 2018 at https://doi.org/10.5066/F7P84B24.

Clark, B.R., Hart, R.M., and Gurdak, J.J., 2011, Groundwater availability of the Mississippi embayment: U.S. Geological Survey Professional Paper 1785, 62 p. [Also available at https://pubs.usgs.gov/pp/1785/.]

Dalsin, G.J., 1978, The Mississippi River Valley alluvial aquifer in Mississippi: U.S. Geological Survey Water-Resources Investigations Report 78-106, 2 pls. [Also available at https://doi.org/10.3133/wri78106.]

Darden, D., 1981, Water-level map of the Mississippi delta alluvium in northwestern Mississippi, April 1981: U.S. Geological Survey Open-File Report 81-1123, 1 pl. [Also available at https://doi.org/10.3133/ofr811123.]

Darden, D., 1982a, Water-level maps of the alluvial aquifer, northwestern Mississippi, September 1981: U.S. Geological Survey Open-File Report 82-574, 1 pl. [Also available at https://doi.org/10.3133/ofr82574.]

Darden, D., 1982b, Water-level maps of the alluvial aquifer, northwestern Mississippi, April 1982: U.S. Geological Survey Water-Resources Investigations Report 82-4061, 1 pl. [Also available at https://doi.org/10.3133/wri824061.]

Darden, D., 1983, Water-level maps of the alluvial aquifer, northwestern Mississippi, September 1982: U.S. Geological Survey Water-Resources Investigations Report 83-4133, 1 pl. [Also available at https://doi.org/10.3133/wri834133.]

Edds, J., and Fitzpatrick, D.J., 1984, Maps showing altitude of the potentiometric surface and changes in water levels of the alluvial aquifer in eastern Arkansas, Spring 1983: U.S. Geological Survey Water-Resources Investigations Report 84-4264, 1 pl. [Also available at https://doi.org/10.3133/ wri844264.]

Engler, K., Bayley, F.H., 3d, and Sniegocki, R.T., 1963, Studies of artificial recharge in the Grand Prairie region, Arkansas; environment and history: U.S. Geological Survey Water-Supply Paper 1615-A, 32 p., 4 pls. [Also available at https://doi.org/10.3133/wsp1615A.]

Esri, 2018, ArcMap version 10.5.1: Redlands, Calif., Esri software documentation [online documentation and instructions included with GIS software]. 
Fenneman, N.M., and Johnson, D.W., 1946, Physical divisions of the United States (Map): Washington, D.C., U.S. Geological Survey, scale 1:7,000,000.

Fetter, C.W., 2001, Applied hydrology (4th ed.): New Jersey, Prentice-Hall, Inc., 598 p.

Freeze, R.A., and Cherry, J.A., 1979, Groundwater: Englewood Cliffs, New Jersey, 604 p.

Hart, R.M., Clark, B.R., and Bolyard, S.E., 2008, Digital surfaces and thicknesses of selected hydrogeologic units within the Mississippi Embayment Regional Aquifer Study (MERAS): U.S. Geological Survey Scientific Investigations Report 2008-5098, 33 p. [Also available at https://pubs.usgs.gov/sir/2008/5098/.]

Helsel, D.R., and Hirsch, R.M, 2002, Statistical methods in water resources: U.S. Geological Survey Techniques of Water-Resources Investigations, book 4, chap. A3, 523 p. [Also available at https://doi.org/10.3133/twri04A3.]

Hosman, R.L., and Weiss, J.S., 1991, Geohydrologic units of the Mississippi embayment and Texas coastal uplands aquifer systems, south-central United States: U.S. Geological Survey Professional Paper 1416-B, 19 p. [Also available at https://doi.org/10.3133/pp1416B.]

Joseph, R.L., 1999, Status of water levels and selected waterquality conditions in the Mississippi River Valley alluvial aquifer in eastern Arkansas, 1998: U.S. Geological Survey Water-Resources Investigations Report 99-4035, 54 p. [Also available at https://doi.org/10.3133/wri994035.]

Kleiss, B.A., Coupe, R.H., Gonthier, G.J., and Justus, B.J., 2000, Water quality in the Mississippi embayment, Mississippi, Louisiana, Arkansas, Missouri, Tennessee, and Kentucky, 1995-98: U.S. Geological Survey Circular 1208, 36 p. [Also available at https://pubs.water.usgs.gov/ circ1208/.]

Krinitzsky, E.L., and Wire, J.C., 1964, Groundwater in the alluvium of the lower Mississippi valley (Upper and Central Areas), v. 1-2: U.S. Army Corps of Engineers, Mississippi River Commission, Waterways Experiment Station, Vicksburg, Miss., Technical Report 3-658, v. 1, 100 p.; v. 2, 377 p. [Also available at http://lmvmapping.erdc.usace.army.mil/.]

Ladd, D.E., and Travers, L.R., 2019, Generalized regions of the Mississippi Alluvial Plain: U.S. Geological Survey data release, accessed April 2019 at https://doi.org/10.5066/ P915ZZQM.

Lohman, S.W., 1972, Ground-water hydraulics: U.S. Geological Survey Professional Paper 708, 70 p. [Also available at https://doi.org/10.3133/pp708.]
Maupin, M.A., and Barber, N.L., 2005, Estimated withdrawals from principal aquifers in the United States, 2000: U.S. Geological Survey Circular 1279, 46 p. [Also available at https://doi.org/10.3133/cir1279.]

McGuire, V.L., Seanor, R.C., Asquith, W.H., Kress, W.H., Strauch, K.R., and Flynn, A.T., 2019, Data associated with potentiometric surface, Mississippi River Valley alluvial aquifer, spring 2016: U.S. Geological Survey data release, https://doi.org/10.5066/P9SV1HMQ.

Miller, D.G., 1999, National Geodetic Survey (NGS) height conversion methodology: National Geodetic Survey's VERTCON program, accessed April 2018 at https://www.ngs.noaa.gov/cgi-bin/VERTCON/vert_con.prl.

Miller, J.A., and Appel, C.L., 1997, Ground water atlas of the United States - Kansas, Missouri, and Nebraska: U.S. Geological Survey Hydrologic Atlas 730-D, 24 p. [Also available at https://pubs.usgs.gov/ha/730d/report.pdf.]

Painter, J.A., and Westerman, D.A., 2018, Mississippi alluvial plain extent, November 2017: U.S. Geological Survey data release, accessed March 2018 at https://doi.org/10.5066/ F70R9NMJ.

Plafcan, M., and Edds, J., 1986, Water level and saturated thickness maps of the alluvial aquifer in eastern Arkansas, 1984: U.S. Geological Survey Water-Resources Investigations Report 86-4014, 1 pl. [Also available at https://doi.org/10.3133/wri864014.]

Plafcan, M., and Fugitt, D.T., 1987, Water-level maps of the alluvial aquifer in eastern Arkansas, 1985: U.S. Geological Survey Water-Resources Investigations Report 86-4178, 1 pl. [Also available at https://doi.org/10.3133/wri864178.]

Plafcan, M., and Remsing, L.M., 1989, Water-level maps of the Mississippi River Valley alluvial aquifer in eastern Arkansas, 1986: U.S. Geological Survey Water-Resources Investigations Report 88-4067, 1 pl. [Also available at https://doi.org/10.3133/wri884067.]

Plebuch, R.O., and Hines, M.S., 1967, Water resources of Pulaski and Saline Counties, Arkansas: U.S. Geological Survey Water Supply Paper 1839-B, 25 p., 1 pl. [Also available at https://doi.org/10.3133/wsp1839B.]

Reed, T.B., 2004, Status of water levels and selected waterquality conditions in the Mississippi River Valley alluvial aquifer in eastern Arkansas, 2002: U.S. Geological Survey Scientific Investigations Report 2004-5129, 53 p. [Also available at https://doi.org/10.3133/sir20045129.] 
Saucier, R.T., 1994, Geomorphology and Quaternary geologic history of the lower Mississippi valley, Volumes I and II: Vicksburg, Mississippi, U.S. Army Corps Engineers Waterways Experiment Station, 414 p., 28 pls, accessed June 2018 at https://biotech.law.lsu.edu/climate/mississippi/ sausier/sausier.htm.

Schrader, T.P., 2001, Status of water levels and selected waterquality conditions in the Mississippi River valley alluvial aquifer in eastern Arkansas, 2000: U.S. Geological Survey Water-Resources Investigations Report 2001-4124, 52 p., 2 pls. [Also available at https://doi.org/10.3133/wri014124.]

Schrader, T.P., 2006, Status of water levels and selected waterquality conditions in the Mississippi River Valley alluvial aquifer in eastern Arkansas, 2004: U.S. Geological Survey Scientific Investigations Report 2006-5128, 82 p., 3 pls. [Also available at https://doi.org/10.3133/sir20065128.]

Schrader, T.P., 2008, Water levels and selected water-quality conditions in the Mississippi River Valley alluvial aquifer in eastern Arkansas, 2006: U.S. Geological Survey Scientific Investigations Report 2008-5092, 78 p., 2 pls. [Also available at https://doi.org/10.3133/sir20085092.]

Schrader, T.P., 2010, Water levels and selected water-quality conditions in the Mississippi River Valley alluvial aquifer in eastern Arkansas, 2008: U.S. Geological Survey Scientific Investigations Report 2010-5140, 71 p., 2 pls. [Also available at https://doi.org/10.3133/sir20105140.]

Schrader, T.P., 2015, Water levels and water quality in the Mississippi River Valley alluvial aquifer in eastern Arkansas, 2012: U.S. Geological Survey Scientific Investigations Report 2015-5059, 63 p., 2 pls., accessed June 2018 at http://dx.doi.org/10.3133/sir20155059.

Seanor, R.C., and Smoot, C.W., 1995, Louisiana ground-water map no. 6-Potentiometric surface, 1990, and water-level changes, 1974-90, of the Mississippi River alluvial aquifer in northeastern Louisiana: U.S. Geological Survey Water-Resources Investigations Report 95-4146, 2 pls., accessed June 2018 at https://pubs.er.usgs.gov/publication/ wri954146.

Stanton, G.P., Joseph, R.L., and Pugh, A.L., 1998, Status of water levels and selected water-quality conditions in the Mississippi River Valley alluvial aquifer in eastern Arkansas, 1994-1996: U.S. Geological Survey WaterResources Investigations Report 98-4131, 72 p. [Also available at https://doi.org/10.3133/wri984131.]

Sumner, D.M., 1984, Water-level maps of the alluvial aquifer, northwestern Mississippi, April 1983: U.S. Geological Survey Water-Resources Investigations Report 83-4285, 1 pl. [Also available at https://doi.org/10.3133/wri834285.]
Sumner, D.M., 1985, Water-level maps of the alluvial aquifer, northwestern Mississippi, September 1983: U.S. Geological Survey Water-Resources Investigations Report 84-4346, 1 pl. [Also available at https://doi.org/10.3133/wri844346.]

U.S. Army Corps of Engineers, 2018, RiverGages.com, Water levels of rivers and lakes: U.S. Army Corps of Engineers digital data, accessed May 2018 at http://rivergages.mvr. usace.army.mil/WaterControl/new/layout.cfm.

U.S. Geological Survey, 2004, Physiographic divisions of the conterminous U.S.: U.S. Geological Survey digital data, accessed June 2018 at https://water.usgs.gov/GIS/dsdl/ physio_cov.zip.

U.S. Geological Survey, 2015, Mississippi River Valley alluvial aquifer: U.S. Geological Survey digital data, accessed June 2018 at https://water.usgs.gov/GIS/dsdl/Mississippi_ River_Valley_alluvial_shp.zip.

U.S. Geological Survey, 2018, USGS water data for the Nation: U.S. Geological Survey National Water Information System database, accessed May 2018 at https://doi.org/10.5066/F7P55KJN.

Wacaster, S.R., Clark, J.M., Westerman, D.A., and Kress, W.H., 2018, Digital dataset for the geomorphology of the Lower Mississippi River Valley in Missouri, Kentucky, Arkansas, Tennessee, Louisiana, and Mississippi: U.S. Geological Survey data release, accessed May 2019 at https://doi.org/10.5066/F7N878QN.

Wasson, B.E., 1980, Water-level map of the Mississippi Delta alluvium in northwestern Mississippi, September 1980: Mississippi Bureau of Land and Water Resources Map 80-1, $1 \mathrm{pl}$.

Westerfield, P.W., 1990, Water-level maps of the Mississippi River Valley alluvial aquifer in eastern Arkansas, 1987: U.S. Geological Survey Water-Resources Investigations Report 90-4089, 1 pl. [Also available at https://doi.org/10.3133/ wri904089.]

Westerfield, P.W., and Gonthier, G., 1993, Water-level maps of the Mississippi River Valley alluvial aquifer in eastern Arkansas, 1989: U.S. Geological Survey Water-Resources Investigations Report 92-4120, 1 pl. [Also available at https://doi.org/10.3133/wri924120.]

Westerfield, P.W., and Poynter, D.T., 1994, Water-level maps of the Mississippi River Valley alluvial aquifer in eastern Arkansas, spring 1992: U.S. Geological Survey Open-File Report 93-374, 1 pl. [Also available at https://doi.org/10.3133/ofr93374.]

Wilson, T.A., and Hosman, R.L., 1987, Geophysical well-log data base for the Gulf Coast aquifer systems, south-central United States: U.S. Geological Survey Open-File Report 87-677, 213 p., 1 pl. [Also available at https://doi.org/10.3133/ofr87677.] 
For more information about this publication, contact:

Director, USGS Nebraska Water Science Center

5231 South 19th Street

Lincoln, NE 68512

402-328-4100

For additional information, visit: https://www.usgs.gov/centers/ne-water

Publishing support provided by the

Rolla and Madison Publishing Service Centers 


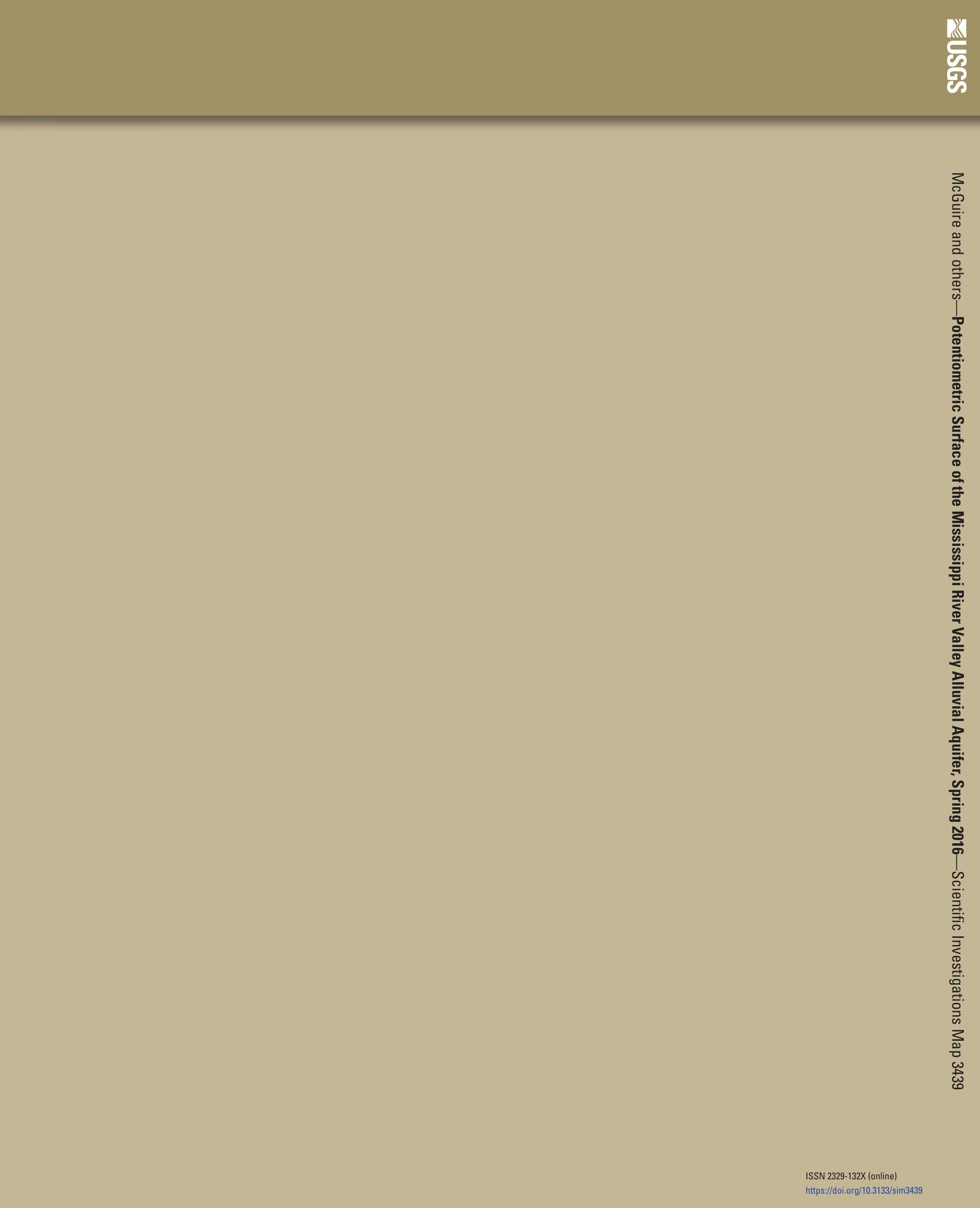

